УДК 37-053.5(73)

DOI: 10.37026/2520-6427-2021-105-1-8-11
Вікторія СЛІПЕНКО,

доктор філософії зі спеціальності

011 «освітні, педагогічні науки»,

викладач кафедри іноземних мов

Уманського державного педагогічного

університету імені Павла Тичини,

м. Умань, Україна

ORCID: 0000-0003-0123-4645

e-mail: slipenkoviktoria@gmail.com

\title{
АНАЛІЗ ЗМІСТУ ПІДПРИЕМНИЦЬКОЇ ОСВІТИ У СУЧАСНІЙ СЕРЕДНІЙ ШКОЛІ США
}

\begin{abstract}
Анотація. Розвиток підприсмницької компетентності - нове педагогічне явище сучасної середньої освіти. Зважаючи на це, формування підприємницької компетентності учнівської молоді на початку третього тисячоліття стало необхідною складовою освітнього прочесу закладів середньої освіти за кордоном, зокрема у Сполучених Штатах Америки - лідера щзодо започаткування підприємств. Підприємництво є ключовим рушієм економіки та успішного процвітання краӥни, значна кількість нових робочих місиь створюється малими і великими підприємствами, започаткованими підприємиями.

У статті на основі аналізу наукових джерел розкрито зміст підприємницької освіти у середніх навчальних закладах США, щчо передбачає достатню кількість розроблених стандартів (Національні
\end{abstract}

стандарти бізнес-освіти та Національні стандарти фінансової грамотності для середніх шкіл США), навчальних програм (з історії та суспільствознавства, що передбачають економічну змістову лінію), курсів («Підприємницька діяльність»), підручників («Підприємецьь: дитячі книги про дітей-підприємщів»), які висвітлюють змістову складову досліджуваного феномену. Крім того, у публікації наголошується, що у процесі розробки та вдосконалення наявних навчальних програм для закладів середньої освіти США із розвитку підприємницької компетентності учнів зазначені стандарти безсумнівно адаптують до суспільних потреб і особливостей політики кожного umamy.

Ключові слова: компетентність, підприємницька компетентність, учні, середня школа, США.

\author{
Viktoriia SLIPENKO, \\ Ph.D in Philosophy, \\ Teacher of Foreign Languages Department \\ Pavlo Tychyna Uman State Pedagogical University, \\ Uman, Ukraine \\ ORCID: 0000-0003-0123-4645 \\ e-mail: slipenkoviktoria@gmail.com
}

\section{THE ANALYSIS OF CONTENT OF ENTREPRENEURIAL EDUCATION IN MODERN SECONDARY SCHOOL OF USA}

\begin{abstract}
Abstact. The development of entrepreneurial competence is a new pedagogical phenomenon of modern secondary education. Entrepreneurship is the key driver of the economy; and the successful prosperity of the country and a significant number of new jobs are created by small and large enterprises founded by entrepreneurs. People involved in entrepreneurial activities claim that they have more opportunities for creative projects, high self-esteem and a sense of control over their own lives. As a result, a significant number of experienced business men, political leaders, economists, and educators believe that the development of entrepreneurial competence maximizes individual, collective, economic, and social success at local, national, and global levels. Therefore, young people who will take a step into adulthood, while studying in high school, should receive the necessary knowledge about the conditions and methods of entrepreneurship, planning and organization of the labour process, lawful behaviour in the business environment, objectively assess
\end{abstract}

their potential and realize their need for the development of society.

It is obvious that the formation of entrepreneurial competence of students at the beginning of the third millennium has become a necessary component of secondary education institutions abroad, in particular in the United States, which is a leader in the launching of enterprises.

The article based on the analysis of scientific sources discloses the essence of entrepreneurial education in secondary schools in the United States, which implies a sufficient number of developed standards (in particular, «National Standards for Business Education» and «National Financial Literacy Standards» for secondary schools in the United States), curricula (in history and social science including economic information), courses ("Entrepreneurial activity»), textbooks ("Entrepreneur: children's books about children entrepreneurs»), which highlight the content component of the investigated phenomenon. It is noted that in the process of developing or improving 
existing curricula for secondary schools in the United States for the development of entrepreneurial competence of students, these standards will undoubtedly adapt to the public needs and peculiarities of the policies of each state.

Key words: competence, entrepreneurial competence, secondary school students, the USA.

Постановка проблеми. Розвиток підприємницької компетентності учнівської молоді на початку третього тисячоліття $є$ необхідною складовою освітнього процесу закладів середньої освіти за кордоном. Усе частіше в найрозвиненіших країнах, зокрема в Сполучених Штатах Америки, педагоги та підприємці стверджують, що потенційні можливості шкільного виховання повністю ще не використані. Більшість підприємців вимагають наявності у найманих робітників системного й аналітичного мислення, комунікабельності, ініціативності, навичок прийняття виважених рішень, відповідальності за свої дії, що необхідні в нинішніх умовах. Безсумнівно, раціональне вирішення цієї проблеми залежить від успішних результатів у формуванні особистості майбутнього працівника на всіх щаблях навчання у середній школі.

18 грудня 2006 року внаслідок багаторічної дискусії представників освітніх установ держав Свропейського Союзу прийнято важливий документ - Рекомендації Європарламенту і Ради Європи «Ключові компетентності для навчання впродовж життя (Свропейські орієнтири)», в якому виокремлено вісім ключових компетентностей, зокрема підприємницьку (Definition and Selection of Competencies, 2019).

Аналіз наукових досліджень і публікацій. Проблема розвитку підприємницької компетентності учнів середніх шкіл США $є$ досить актуальною, але й водночас малодослідженою в Україні.

Теоретичні підходи щодо формування підприємницької компетентності молоді США неодноразово ставали предметом дослідження науковців. Зокрема, у своїй праці «Підприємництво: шлях вперед» (Entrepreneurship: The way ahead) Г. Вельш (Harold Welsch, 2004) висвітлює розуміння та перспективи розвитку підприємництва та передових лідерів у цій галузі. Науковці Дж. Дірі та К. Гедулдіг (John Dearie \& Courtney Geduldig, 2013) описують, яким чином американське суспільство може відновити створення робочих місць за рахунок підприємницької діяльності. Американський дослідник П. Рейнольдс (Paul D. Reynolds, 2007) визначає підприємництво однією із найяскравіших і найважливіших галузей економіки та надає систематизований огляд основних закономірностей у процесі створення фірми тощо.

Крім того, дослідниками А. Стенфордом, А. Стюарт, Дж. Клоу (Stafford, Allen, Clow, 2005) запропоновано методичний посібник для вчителів «Підприємництво в економіці США» (Entrepreneurship in the U.S. economy), розроблений із метою навчання учнів на економічних курсах, що сприяє розвитку навичок успішних підприємців, розширює розуміння того, як функціонує бізнес. Американським професором Джеймсом Харті (James D. Hart, 2018) розроблені «Класні заняття для підприємництва: міждисциплінарний підхід (Вказівки Елгарда до навчання)» (Classroom Exercises for Entrepreneurship: A Cross-disciplinary Approach (Elgar Guides to Teaching).
Автор підкреслює, що підприємництво - це творча практика, тому традиційний підхід до навчання цього складного предмета не завжди є достатнім, оскільки учні отримують більше користі від практичного досвіду.

Проте, незважаючи на означені напрацювання, зміст підприємницької освіти у сучасній середній школі США ще не став предметом спеціального дослідження.

Мета статті - на основі опрацювання наукових джерел здійснити аналіз змісту підприємницької освіти у сучасній середній школі США.

Виклад основного матеріалу дослідження. Вивчення змісту підприємницької освіти у середніх навчальних закладах США, що є визначальним фактором розвитку в учнів підприємницької компетентності, дозволяє стверджувати, що в цій країні науковцями і педагогами розроблена достатня кількість стандартів, програм, курсів, що висвітлюють змістову складову досліджуваного феномену.

Очевидно, що зміст шкільної підприємницької освіти $є$ предметом пріоритетної уваги американської педагогічної спільноти, оскільки у 2013 році Національна асоціація бізнес-освіти (National Business Education Association - NBEA), заснована в 1914 році як провідна організація щодо питань підготовки вчителів, розробки відповідних методичних матеріалів і реформ змісту економічної освіти (первинне найменування Об'єднана рада з економічної освіти), опублікувала Національні стандарти бізнес-освіти (4 видання), вперше видані в 1995 році на прохання педагогів сфери бізнесу. В означеному документі представлені оновлені стандарти бізнес-освіти, що включають перелік предметних галузей, із-поміж яких - підприємництво.

Усього визначено 9 стандартів:

Стандарт 1. Підприємці та їхні можливості здатність аналізувати власні характеристики і визначати їх роль для підприємницької діяльності.

Стандарт 2. Напрями підприємництва - обізнаність із основними напрямами підприємництва, що відкривають нові можливості для власної справи.

Стандарт 3. Економіка - готовність використовувати економічні концепції у ході створення власного підприємства.

Cтандарт 4. Маркетинг - уміння здійснювати маркетингові дії під час введення продукту або послуги на ринок збуту.

Стандарт 5. Фінанси - можливість застосовувати фінансові концепції та засоби, необхідні підприємцеві у ході прийняття ділових рішень.

Стандарт 6. Бухгалтерський облік - спроможність встановлювати, підтримувати і аналізувати документацію, необхідну для підприємницької діяльності.

Стандарт 7. Менеджмент - здатність розробляти план управління підприємством.

Стандарт 8. Законодавство - можливість здійснювати аналіз форм підприємницької власності, державних постанов, правових норм та їх впливу на підприємницьку діяльність.

Стандарт 9. Бізнес-план - уміння розробляти бізнес-план на основі конкретної ділової ідеї (National Standards For Business Education, 2013, p. 65-76).

Варто також виокремити прийняті у 2013 році Національні стандарти бізнес-освіти, Національні стандарти фінансової грамотності, розроблені Радою з економічної освіти (the Council for Economic Education's CEЕ) - провідною організацією у Сполучених Штатах, що спеціалізується на економічній та фінансовій освіті 
учнів, починаючи з дитячого садка та впродовж усього навчання у середній школі.

Отже, фінансова грамотність підприємця - це сукупність знань, які дозволяють йому приймати правильні, виважені рішення щодо управління своїми фінансами 3 метою досягнення поставлених планів і цілей. Зазначені стандарти передбачають розуміння обліку доходів і витрат, планування бізнесу, орієнтування в основних кредитних інструментах для власної справи, розуміння податкового законодавства, управління руху коштами. Усе це необхідно підприємцю для прийняття грамотних управлінських рішень, що дозволяють мінімізувати витрати і збільшити прибуток створюваного бізнесу. Основні положення цих стандартів змісту підприємницької освіти розкриті завдяки таким складовим: отримання доходу, придбання товарів та послуг, заощадження, використання кредиту, фінансові інвестиції, захист і страхування (National Standards For Financial Literacy, 2013).

Однак, незважаючи на те, що освіта країни підтримується федеральними органами, система навчання у США залишається переважно децентралізованою, зокрема для кожного штату характерні власні законодавчі освітні документи, що вирішують проблеми щодо стандартів, навчальних програм, критеріїв оцінювання, вибору навчального матеріалу тощо. Безумовно, нині у Сполучених Штатах не існує єдиних обов'язкових стандартів із підприємницької освіти для закладів середньої освіти, оскільки, нагальною проблемою для країни так і залишається розроблення та впровадження таких, корті б визначали достатній рівень знань школярів, враховуючи особливості освітньої політики кожного штату та використовуючи запропоновані стандарти як рекомендовані освітні документи.

У штаті Массачусетс, наприклад, створена навчальна програма 3 історії та суспільствознавства (Massachusetts History and Social Science Curriculum Framework), розроблена з опорою на Національні стандарти фінансової грамотності та Національні стандарти бізнес-освіти, оскільки окрім базових знань з історії, географії, громадяноведення та урядування містить економічну змістову лінію для всіх етапів навчання (Massachusetts History and Social Science Curriculum Framework, 2003, p. 1-84).

У штаті Нью-Йорк видано та рекомендовано відділом освіти (The University of the State of New York - USNY) програму із суспільствознавства для дітей дошкільного віку до 8 класу (К-8 Social Studies Framework), розроблену за національними стандартами. Вона містить характеристику базових знань із предметів суспільного спрямування, котрі стосуються підприємництва (New York State K-8 Social Studies Framework, 2013, p. 107).

Відділом освіти штату Північна Дакота (South Dakota Department of Education) також розроблено Стандарти із суспільних наук (The South Dakota Social Studies Standards) 3 опорою на національні документи для всіх етапів навчання з метою забезпечення випускників середніх шкіл знаннями, навичками, необхідними для ведення продуктивного, успішного життя після закінчення школи. Підприємницька компетентність, виявлена в стандартах - одна із основних складових документа, формування котрої здійснюється за принципами систематичності та послідовності навчання (South Dakota Social Studies Standards, 2006).

Відділом освіти штату Джорджія розроблений власний курс «Підприємницька діяльність»
(Entrepreneurial Ventures) без опори на національні стандарти, що $є$ частиною програми «Шлях до кар'єри - розвиток малого бізнесу» (Small Business Development Career Pathway), доступний лише для учнів старшої школи та зосереджений на управлінських навичках, необхідних для успішного ведення бізнесу. Учні вивчають: стратегії управління, розробки та реалізації бізнес-планів; структуру організації та іiі фінансування; управління інформацією, операціями, маркетингом та людськими ресурсами; міжнародні бізнес-принципи. Невід'ємним компонентом навчального курсу є реально засноване підприємство в школах або на рівні громади, котре залучає учнів до створення та управління бізнесом і стимулює відкрити власну справу. Успішне опанування курсу досягається шляхом навчання на основі проєктної діяльності та розвитку лідерських якостей майбутніх підприємців США, що беззаперечно сприяє підготовці школярів до конкурентної переваги на глобальному ринку праці.

У середніх школах штату Алабама користуються Національними стандартами фінансової грамотності (National Standards for Financial Literacy), за якими розроблений курс «Суспільні науки» (Social studies course) для учнів 4-8 класів, що пов'язаний із підприємництвом. Заслуговує на увагу впровадження в американський шкільний процес серії літератури «Підприємець: дитячі книги про дітей-підприємців» (Entrepreneur Kid: Children's Books about Kid Entrepreneurs) (Stories of real kids with real businesses, 2019), де подані історії юних підприємців, котрі розпочали та продовжують розвивати справжній бізнес.

Відділом освіти штату Оклахома (Oklahoma State Department of Education - OSDE) створені Академічні стандарти із суспільних наук для всіх етапів навчання (Academic standards for the social studies K-12) із опорою на Національні стандарти фінансової грамотності (National Standards for Financial Literacy). Основи підприємницької майстерності учні опановують лише у старшій школі. Окрім підприємницької підготовки, молодь навчається застосовувати навички економічного обгрунтування, вивчає американську систему вільного ринку, роль уряду Сполучених Штатів та Федеральної резервної системи (Oklahoma academic standards for the social studies, 2013, p. 37-40).

Висновки. Отже, проаналізувавши зміст підприємницької освіти у сучасній середній школі США, що представлений національними стандартами, стандартами, розробленими на рівні окремих штатів, навчальними програмами та курсами, можна констатувати, що незважаючи на значний за обсягом матеріал, передбачений для опрацювання учнями, вчителі прагнуть отримати реальний результат своєї роботи, причому не лише завдяки оволодінню необхідними знаннями, а завдячуючи практичній діяльності школярів.

Перспективи подалыших досліджень. Можливі шляхи використання американського досвіду щодо формування підприємницької компетентності учнів в Україні вбачаємо у використанні представлених матеріалів у середніх навчальних закладах, зокрема у процесі розроблення навчальних програм з економіки чи основ підприємництва. Крім того, потребують дослідження питання вивчення методики діагностування підприємливості учнів України та США, розвитку підприємницької компетентності американської учнівської молоді в умовах неформальної освіти. 


\section{REFERENCES}

DeSeCo. Definition and Selection of Competencies. Theoretical and Conceptual Foundations (DESECO). Strategy Paper on Key Competencies. An Overarching Frame of Reference for an Assessment and Research Program. OECD (Draft). URL: http://www.deseco.admin.ch/ (дата звернення: 12.09.2020). [in English].

Welsch, H. (2004). Entrepreneurship: The way ahead. New York: Routledge. 302 p. [in English].

Dearie, J. Geduldig, C. (2013). Where the Jobs Are: Entrepreneurship and the soul of American economy. Hoboken; New Jersey: Wiley. 272 p. [in English].

Reynolds, P. (2007). Entrepreneurship in the United States: The Future Is Now. New York: Springer. 236 p. [in English].

Stafford, A., Allen, S., Clow, J. (2005). Entrepreneurship in the U.S. economy: Teacher resource manual. New York: National Council on Economic Education. 170 p. [in English].

Hart, J. D. (2018). Classroom Exercises for Entrepreneurship: A Cross-Disciplinary Approach (Elgar Guides to Teaching). Cheltenham; Gloucestershire: Edward Elgar Publishing, Incorporated. 328 p. [in English].

National Business Education Association (2013). National standards for business education: What America's students should know and be able to do in business. Reston. P. 65-76. [in English].

Council for Economic Education (2013). National standards for financial literacy. New York. 42 p. [in English].

Massachusetts Department of Elementary and Secondary Education (2018). Massachusetts History and Social Science Curriculum Framework. Public Comment Draft. January. 192 p. [in English].

The State Education Department \& The University of the State of New York (2017). New York State K-8 Social Studies Framework. 109 p. [in English].

South Dakota Dept. of Education and Cultural Affairs. (2006). South Dakota social studies content standards. [Pierre]. 117 p. [in English].

Entrepreneur Kid: Children's Books about Kid Entrepreneurs (Stories of real kids with real businesses). URL: http://www.entrepreneurkid.com/ (дата звернення: 12.12.2019). [in English].

Oklahoma State Department of Education. Oklahoma academic standards for the social studies. Publications clearinghouse of the Oklahoma department of libraries (2013). P. 37-40. [in English].

Дата надходження до редакиії: 12.02.2021 p. 